\title{
Breadth of concomitant immune responses underpinning viral clearance and patient recovery in a non-severe case of COVID-19
}

Irani Thevarajan ${ }^{1,2 \#}$, Thi HO Nguyen ${ }^{3 \#}$, Marios Koutsakos ${ }^{3}$, Julian Druce ${ }^{4}$, Leon Caly ${ }^{4}$, Carolien E van de Sandt ${ }^{3,5}$, Xiaoxiao $\mathrm{Jia}^{3}$, Suellen Nicholson ${ }^{4}$, Mike Catton ${ }^{4}$, Benjamin Cowie ${ }^{1,2}$, Steven YC Tong ${ }^{1,2,6}$, Sharon R Lewin ${ }^{2,3,7}$ and Katherine Kedzierska*

\section{Affiliations}

${ }^{1}$ Victorian Infectious Diseases Service, The Royal Melbourne Hospital at the Peter Doherty Institute for Infection and Immunity, Melbourne 3000, Victoria, Australia.

${ }^{2}$ Doherty Department, The University of Melbourne at The Peter Doherty Institute for Infection and Immunity, Melbourne 3000, Victoria, Australia.

${ }^{3}$ Department of Microbiology and Immunology, The University of Melbourne, at the Peter Doherty Institute for Infection and Immunity, Parkville 3010, Victoria, Australia.

${ }^{4}$ Victorian Infectious Diseases Reference Laboratory, The Royal Melbourne Hospital at The Peter Doherty Institute for Infection and Immunity, Melbourne 3000, Victoria, Australia.

${ }^{5}$ Department of Hematopoiesis, Sanquin Research and Landsteiner Laboratory, Amsterdam UMC, University of Amsterdam, 1066CX Amsterdam, Netherlands

${ }^{6}$ Menzies School of Health Research, Charles Darwin University, Darwin, Australia.

${ }^{7}$ Department of Infectious Diseases, Alfred Hospital and Monash University, Melbourne, 3010, Victoria, Australia

*Correspondence: kkedz@,unimelb.edu.au; ; authors contributed equally.

Running title: COVID-19 and cellular immunity 
We report the kinetics of the immune response in relation to clinical and virological features of a patient with mild-to-moderate coronavirus disease-19 (COVID-19) requiring hospitalisation. Increased antibody-secreting cells, follicular T-helper cells, activated $\mathrm{CD4}^{+}$and $\mathrm{CD8}^{+}$T-cells and IgM/IgG SARSCoV-2-binding antibodies were detected in blood, prior to symptomatic recovery. These immunological changes persisted for at least 7 days following full resolution of symptoms, indicating substantial anti-viral immunity in this non-severe COVID-19.

On 30/01/2020, a 47-year old woman from Wuhan, Hubei province, China presented to an emergency department in Melbourne, Australia. Her symptoms commenced 4 days earlier with lethargy, sore throat, dry cough, pleuritic chest pain, mild dyspnoea and subjective fevers (Fig.1a). She had travelled 11 days prior to presentation from Wuhan via Guangzhou to Australia. She had no contact with the Huanan seafood market or known COVID-19 cases. She was otherwise healthy, non-smoker, taking no medications. Clinical examination revealed a temperature of $38.5^{\circ} \mathrm{C}$, pulse rate 120 beats/minute, blood pressure $140 / 80 \mathrm{mmHg}$, respiratory rate 22 breaths/minute, and oxygen saturation $98 \%$, while breathing ambient air. Lung auscultation revealed bibasal rhonchi. At presentation day (d) 4, SARS-CoV-2 was detected by real-time reverse transcriptase polymerase-chain-reaction (rRT-PCR) from a nasopharyngeal swab specimen. SARS-CoV-2 was again detected at d5-6 from nasopharyneal, sputum and faecal samples, but was undetectable from d7 (Fg.1a). Blood C-reactive protein was elevated at 83.2 , with normal lymphocyte counts $\left(4.3 \times 10^{9} / \mathrm{L}\right.$ [range 4.0 $\left.\left.12.0 \times 10^{9} / \mathrm{L}\right]\right)$ and normal neutrophil counts $\left(6.3 \times 10^{9} / \mathrm{L}\right.$ [range $\left.\left.2.0-8.0 \times 10^{9} / \mathrm{L}\right]\right)$. No other respiratory pathogens were detected. Her management was intravenous fluid rehydration without supplemental oxygenation. No antibiotics, steroids or antiviral agents were administered. Chest radiography demonstrated bibasal infiltrates at $\mathrm{d} 5$, which cleared on d10 (Fig.1b), and she was discharged to home isolation on d11. Symptoms resolved completely by $\mathrm{d} 13$ and she remained well at $\mathrm{d} 20$ post-onset of symptoms. Progressive increase in plasma COVID-19-binding IgM/IgG antibodies, from d7 until d20 was observed (Fig.1c).

There are currently no data defining immune responses leading to viral clearance and clinical resolution of COVID-19. We addressed this knowledge gap by analysing the breadth of immune responses in blood prior to patient recovery. As antibody-secreting cells (ASCs) are key for the rapid production of antibodies following viral Ebola infection ${ }^{1,2}$, influenza virus infection and vaccination ${ }^{2,3}$; and activated circulating follicular $\mathrm{T}$ helper (cTfhs) are concomitantly induced following influenza vaccination ${ }^{3}$, we first determined the frequency of $\mathrm{CD} 3{ }^{-} \mathrm{CD} 19^{+} \mathrm{CD} 27^{\mathrm{hi}} \mathrm{CD} 38^{\mathrm{hi}} \mathrm{ASCs}$ and $\mathrm{CD}^{+} \mathrm{CXCR}^{+} \mathrm{ICOS}^{+} \mathrm{PD} 1^{+}$cTfh responses at 3 days prior to symptomatic recovery. ASCs appeared in blood at the time of viral clearance at $\mathrm{d} 7(1.48 \%)$ and peaked on $\mathrm{d} 8(6.91 \%)$. Emergence of cTfhs occurred concurrently in blood at $\mathrm{d} 7$ (1.98\%), with the frequency increasing on $\mathrm{d} 8(3.25 \%)$ and $\mathrm{d} 9(4.46 \%)$ (Fig.2a). The peak of both ASCs and cTfhs was markedly higher in the COVID-19 patient than the baseline levels in healthy controls (average \pm SD: $0.61 \pm 0.40 \%$ and $1.83 \pm 0.77 \%$, respectively, $n=5$ ). Both ASCs and cTfhs were still prominently present at convalescence (d20) (4.54\% and 7.14\%, respectively; Fig.2a). Our study provides evidence on the recruitment of both ASCs and cTfhs in patient's blood whilst still 
unwell and 3 days prior to resolution of symptoms, indicating their importance in anti-viral immunity towards SARS-CoV-2.

Since co-expression of CD38 and HLA-DR is well defined as the key phenotype of $\mathrm{CD} 8^{+} \mathrm{T}$-cell activation towards viral infections, we analyzed activation of $\mathrm{CD} 8^{+} \mathrm{T}-$ cells by CD38/HLA-DR co-expression. In accordance with previous reports on Ebola and influenza ${ }^{1,4}, \mathrm{CD} 38^{+} \mathrm{HLA}-\mathrm{DR}^{+}$co-expression on $\mathrm{CD} 8^{+} \mathrm{T}$-cells rapidly increased from $\mathrm{d} 7(3.57 \%)$ to $\mathrm{d} 8(5.32 \%)$ and $\mathrm{d} 9(11.8 \%)$, with a decrease at $\mathrm{d} 20(7.05 \%)$ (Fig.2b). Furthermore, the frequency of $\mathrm{CD} 38^{+} \mathrm{HLA}_{-} \mathrm{DR}^{+}$co-expression on $\mathrm{CD} 8^{+} \mathrm{T}$ cells in this patient was markedly higher than on $\mathrm{CD} 8^{+} \mathrm{T}$-cells in healthy individuals $(1.47 \pm 0.50 \%, \mathrm{n}=5)$. Similarly, $\mathrm{CD} 38^{+} \mathrm{HLA}^{-\mathrm{DR}^{+}}$co-expression increased on $\mathrm{CD}^{+} \mathrm{T}$-cells between $\mathrm{d} 7(0.55 \%)$ and $\mathrm{d} 9(3.33 \%)$ in the patient, compared to healthy donors $(0.63 \pm 0.28 \%, \mathrm{n}=5)$, although at lower levels than $\mathrm{CD} 8^{+} \mathrm{T}$-cells.

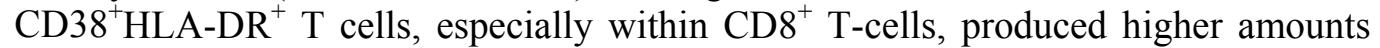
of granzymes $\mathrm{A} / \mathrm{B}$ and perforin $\left(\sim 34-54 \%\right.$ higher) than their parent $\left(\mathrm{CD} 8^{+}\right.$or $\mathrm{CD} 4^{+}$ populations, Fig.2b). Thus, the emergence and rapid increase in activated

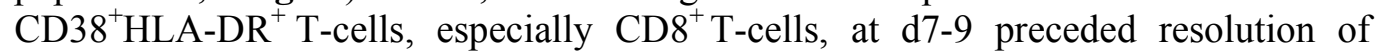
symptoms.

We also analysed $\mathrm{CD} 16^{+} \mathrm{CD} 14^{+}$monocytes, related to immunopathology, and activated $\mathrm{HLA}-\mathrm{DR}^{+} \mathrm{CD}{ }^{-} \mathrm{CD} 56^{+} \mathrm{NK}$ cells (Fig.2c). We detected reduced frequencies of $\mathrm{CD} 16^{+} \mathrm{CD} 14^{+}$monocytes in peripheral blood at $\mathrm{d} 7-9(1.29 \%, 0.43 \%, 1.47 \%$, respectively), compared to healthy controls $(9.03 \pm 4.39 \%, n=5)$. This might indicate efflux of $\mathrm{CD} 16^{+} \mathrm{CD} 14^{+}$monocytes from blood to the site of infection, which remained low at $\mathrm{d} 20(2.24 \%)$. Low levels of activated HLA-DR ${ }^{+} \mathrm{CD} 3^{-} \mathrm{CD} 56^{+} \mathrm{NK}$ cells were found in both the COVID-19 patient and healthy controls.

As high levels of pro-inflammatory cytokines/chemokines are predictive of severe clinical outcomes for influenza ${ }^{5}$, seventeen pro-inflammatory cytokines/chemokines were quantified in patient's plasma. We found low levels of monocyte chemoattractant protein-1 (MCP-1; CCL2), important for the recruitment of monocytes, T-cells and dendritic cells to the site of infection (Fig.2d). However, these MCP-1 levels were similar to healthy donors $(22.15 \pm 13.81, n=5)$, patients infected with influenza A (IAV) and influenza B viruses (IBV) at d7-9 $(33.85 \pm 30.12, n=5)$ and a patient with a known human coronavirus infection $\mathrm{HCoV}-229 \mathrm{e}(\mathrm{hCoV}, 40.56)$. Substantial levels of RANTES (CCL5), involved in homing and migration of activated T-cells that express CCR5, were also detected in COVID-19 plasma but these were comparable to healthy donors $(\mathrm{p}=0.412)$, IAV/IBV-infected patients $(\mathrm{p}=0.310)$ and a hCoV-patient. Thus, in contrast to severe avian H7N9 disease with highly elevated IL-6 and IL-8, and intermediate IL-10, MIP-1 $\beta$, IFN- $\gamma^{5}$, minimal proinflammatory cytokines/chemokines were found in this patient with CoVID-19, even while symptomatic at $\mathrm{d} 7-9$.

Given that interferon-induced transmembrane protein-3 (IFITM3) single nucleotide polymorphism (SNP)-rs $12252-\mathrm{C} / \mathrm{C}$ was linked to severe influenza, ${ }^{5,6}$, we analysed the IFITM3- rs12252 SNP in this patient with COVID-19. Interestingly, the patient had the 'risk' IFITM3-rs12252-C/C variant (Fig.2e), associated with clinical compromise for $2009-\mathrm{pH}_{1 \mathrm{~N}} 1^{6}$ and severe/fatal avian H7N9 disease ${ }^{5}$. As the relative prevalence of IFITM3-rs12252-C/C risk variant in a healthy Chinese population is $26.5 \%$ (data from 1,000 genome project $)^{5}$, further investigations of the IFITM3-rs 12252-C/C allele 
144 in larger cohorts of patients with COVID-19 and its correlation with disease severity

145 is worth pursuing.

146

147

148

149

150

151

152

153

154

155

156

157

158

159

160

161

162

163

164

165

166

167

168

169

170

171

172

173

174

175

176

177

178

179

180

181

182

183

184

185

186

187

188

189

190

191

192

193

Collectively, our study provides novel contributions to the understanding of the breadth of the immune response during a non-severe case of COVID-19. This patient did not experience complications of respiratory failure, acute respiratory distress syndrome, did not require supplemental oxygenation and was discharged within a week of hospitalization, consistent with non-severe but clearly symptomatic disease. We provide evidence on the recruitment of immune populations (antibody-secreting B cells, follicular T-cells, activated $\mathrm{CD}_{4}^{+}$and $\mathrm{CD} 8^{+} \mathrm{T}$-cells), together with IgM-IgG SARS-CoV-2-binding antibodies, in patient's blood prior to resolution of clinical symptoms. We propose that these immune parameters should be characterised in larger cohorts of patients with COVID-19 with different disease severity to understand whether they could be used to predict disease outcome and to evaluate new interventions to minimise severity and/or to inform protective vaccine candidates. Furthermore, our study indicates that robust multi-factorial immune responses can be elicited towards the newly-emerged SARS-CoV-2, and similar to the avian H7N9 disease ${ }^{7}$, early adaptive immune responses might correlate with better clinical outcomes.

\section{References}

1. $\quad$ McElroy, A.K. et al. Proc Natl Acad Sci USA 112, 4719-4724 (2015).

2. Ellebedy, A.H. et al. Nat Immunol 17, 1226-1234 (2016).

3. Koutsakos, M. et al. Sci Transl Med 10 (2018).

4. Wang, Z. et al. Nat Commun 9, 824 (2018).

5. Wang, Z. et al. Proc Natl Acad Sci USA 111, 769-774 (2014).

6. Everitt, A.R. et al. 484, 519-523 (2012).

7. Wang, Z. Nat Commun 6: 6833 (2015).

Fig.1. Time course of clinical presentation and detection of SARS-CoV-2 in a range of clinical specimens and antibodies to SARS-CoV2 in blood. (a) Timeline of COVID-19; detection of SARS-CoV-2 virus in sputum, nasopharyngeal aspirates, faeces but not urine, rectal swab and whole blood. SARS-CoV-2 was quantified by real-time RT-PCR and the cycle threshold $(\mathrm{Ct})$ is shown for each of the specimen. An increase in $\mathrm{Ct}$ value is consistent with a decrease in viral load. The assay limit of detection (LOD) threshold is $\mathrm{Ct}=45$. Open circles: undetectable SARS-CoV-2; (b) Radiological improvement from admission to discharge from hospital. Anteroposterior chest radiographs on $\mathrm{d} 5$ (day of admission) and d10 following onset of symptoms; (c, d) Immunofluorescence antibody staining for the detection of $\operatorname{IgG}$ and IgM bound to SARS-CoV-2-infected vero cells using plasma (diluted 1:20) collected at $\mathrm{d} 7-9$ and $\mathrm{d} 20$ following onset of symptoms.

Fig.2. Emergence of immune responses during non-severe symptomatic COVID19. Frequencies of (a) $\mathrm{CD} 27^{\mathrm{hi}} \mathrm{CD} 38^{\text {hi }}$ antibody-secreting cells (ASC; plasmablasts, gated on $\mathrm{CD}^{-} \mathrm{CD} 19^{+}$lymphocytes) and activated $\mathrm{ICOS}^{+} \mathrm{PD}^{+}$follicular $\mathrm{T}$ helper (Tfh) cells (gated on $\mathrm{CD}^{+} \mathrm{CXCR}^{+}$lymphocytes); (b) activated $\mathrm{CD}^{+} 8^{+} \mathrm{HLA}-\mathrm{DR}^{+}$ $\mathrm{CD} 8^{+}$and $\mathrm{CD}^{+}{ }^{+}$-cells; (c) lineage ${ }^{-} \mathrm{CD} 14^{+} \mathrm{CD} 16^{+}$monocytes and activated HLA-DR ${ }^{+}$ NK cells (gated on $\mathrm{CD}^{-} \mathrm{CD} 14^{-} \mathrm{CD} 56^{+}$cells) detected by flow cytometry for blood 
collected at $\mathrm{d} 7-\mathrm{d} 9$ and $\mathrm{d} 20$ following onset of symptoms and in healthy donors (median with IQ range); (b) Histograms and line graphs of granzymes $\mathrm{A} / \mathrm{B} / \mathrm{K} / \mathrm{M}$ and perforin (Prf) staining of parent $\mathrm{CD} 8^{+}$or $\mathrm{CD}^{+} \mathrm{T}$ cells and activated $\mathrm{CD} 38^{+} \mathrm{HLA}-$ $\mathrm{DR}^{+} \mathrm{CD} 8^{+} / \mathrm{CD}^{+} \mathrm{T}$-cells are shown (bottom panels). (d) Plasma levels of proinflammatory cytokines/chemokines in COVID-19 patient at d7-9, healthy individuals $(\mathrm{n}=5$, mean \pm SEM), patient with $\mathrm{HCoV}-229 \mathrm{e}$ and influenza-infected patients $(\mathrm{n}=5)$. (e) 'risk' IFITM3-rs12252 genotyping for the COVID-19 patient.

\section{Acknowledgments}

The authors thank Prof Cameron Simmons for supporting the development of SETREP-ID, all the SETREP-ID investigators for their support and Australian Partnership for Preparedness Research for Infectious Disease Emergencies (APPRISE) for ongoing funding of SETREP-ID. We thank Dr Louise Rowntree for technical assistance. This work was funded by the Australian National Health and Medical Research Council (NHMRC) Investigator Grant to KK (\#1173871). CES has received funding from the European Union's Horizon 2020 research and innovation programme under the Marie Skłodowska-Curie grant agreement No 792532 and University of Melbourne McKenzie Fellowship laboratory support. KK is supported by a NHMRC Senior Research Fellowship Level B (\#1102792) and SRL is supported by an NHMRC Practitioner Fellowship and an NHMRC program grant. SYCT is supported by a NHMRC Career Development Fellowship (\#1145033). XJ is supported by China Scholarship Council-University of Melbourne joint Scholarship. The authors wish to acknowledge our public health partners, and VIDRL's major funder, the Victorian Department of Health and Human Services without whom this work would not have been possible, and the clinical and laboratory staff involved in the care of this patient.

\section{Online content}

\section{Author contribution}

IT, THON, MK, CES, LC, SN, XJ, JD, MK, BC, SYT, SRL, KK formulated ideas, designed the study and experiments; THON, MK, CES, LC, SN, XJ, JD performed experiments; THON, MK, LC, SN, JD analysed the experimental data, KK, IT, THON, SYT, BC, SRL wrote the manuscript. All authors reviewed the manuscript.

\section{Competing interests}

The authors declare no conflict of interest. SRL's institution has received funding for investigator initiated research grants from Gilead Sciences, Merck, Viiv Healthcare and Leidos. She has received honoraria for participation in advisory boards and educational activities for Gilead Sciences, Merck, Viiv Healthcare and Abbvie.

\section{Methods}

\section{Study design}

The patient was enrolled through the Sentinel Travelers Research Preparedness Platform for Emerging Infectious Diseases novel coronavirus substudy (SETREP-ID $\mathrm{coV})$. Sputum, nasopharyngeal aspirates, urine and faecal specimens as well as whole 
blood in sodium heparin tubes were collected over the duration of illness and 9 days post discharge for quantitative virology, immunology and assessment of host gene factors. Human experimental work was conducted according to the Declaration of Helsinki Principles and according to the Australian National Health and Medical Research Council Code of Practice. Participants provided written informed consent prior to the study. The study was approved by the Royal Melbourne Hospital (HREC Reference number: HREC/17/MH/53 and HREC/15/MonH/64/2016.196) and University of Melbourne (ID \#1442952.1 and \#1443389.4) Human Research Ethics Committees.

\section{Generation of SARS-CoV-2 cDNA}

RNA was extracted from $200 \mu \mathrm{L}$ from patient's swabs (nasopharyngeal, rectal, throat in VTM), sputum, urine, faeces and whole-blood samples using the QIAamp 96 Virus QIAcube HT Kit (Qiagen, Hilden, Germany). Reverse transcription was performed using the BioLine SensiFAST cDNA kit (Bioline, London, United Kingdom). Total reaction mixture of $20 \mu \mathrm{l}$ contained $10 \mu \mathrm{L}$ of the RNA extract, $4 \mu \mathrm{l}$ of $5 \mathrm{x}$ TransAmp buffer, $1 \mu \mathrm{l}$ of Reverse Transcriptase and $5 \mu \mathrm{l}$ of Nuclease free water. Reactions were incubated at $25^{\circ} \mathrm{C}$ for $10 \mathrm{~min}, 42^{\circ} \mathrm{C}$ for $15 \mathrm{~min}, 85^{\circ} \mathrm{C}$ for $5 \mathrm{~min}$.

\section{Nested SARS-CoV-2 RT-PCR and Sanger sequencing}

A PCR mixture containing $2 \mu \mathrm{l}$ cDNA, $1.6 \mu \mathrm{l}$ of $25 \mathrm{mM} \mathrm{MgCl}_{2}, 4 \mu \mathrm{l}$ of $10 \mathrm{x}$ Qiagen Taq Buffer, $0.4 \mu \mathrm{l}$ of $20 \mathrm{mM}$ dNTPs, $0.3 \mu \mathrm{l}$ of Taq polymerase (Qiagen, Hilden, Germany) and $2 \mu \mathrm{l}$ of $10 \mu \mathrm{M}$ primer pools as described ${ }^{11}$. The first round included the forward (5'-GGKTGGGAYTAYCCKAARTG-3') and reverse (5'GGKTGGGAYTAYCCKAARTG-3') primers. Cycling conditions were $94^{\circ} \mathrm{C}$ for 10 min, followed by 30 cycles of $94^{\circ} \mathrm{C}$ for $30 \mathrm{~s}, 48^{\circ} \mathrm{C}$ for $30 \mathrm{~s}$ and $72^{\circ} \mathrm{C}$ for $40 \mathrm{~s}$, with a final extension of $72^{\circ} \mathrm{C}$ for $10 \mathrm{~min}$. PCR product $(2 \mu \mathrm{l})$ was used in the second round PCR reaction which included the forward (5'-GGTTGGGACTATCCTAAGTGTGA$\left.3^{\prime}\right)$ and reverse (5'-CCATCATCAGATAGAATCATCAT-3') primers. Cycling conditions were $94^{\circ} \mathrm{C}$ for $10 \mathrm{~min}$, followed by 40 cycles of $94^{\circ} \mathrm{C}$ for $30 \mathrm{~s}, 50^{\circ} \mathrm{C}$ for $30 \mathrm{~s}$ and $72^{\circ} \mathrm{C}$ for $40 \mathrm{~s}$, with a final extension of $72^{\circ} \mathrm{C}$ for $10 \mathrm{~min}$. PCR products had an expected size of approximately $440 \mathrm{bp}$ on a $2 \%$ agarose gel. The PCR products were purified using ExoSAP-IT (Affymetrix, Santa Clara, CA, USA) and sequenced using an Applied Biosystems SeqStudio Genetic Analyzer (Life Technologies, Carlsbad, CA, USA) using Big Dye Terminator 3.1 (Life Technologies, Carlsbad, CA, USA) and Round 2 PCR primers above. SARS-CoV and 229e-CoV cDNA were used as positive controls.

\section{Detection of SARS-CoV-2 using TaqMan Real-time RT-PCR E-gene assay} TaqMan RT-PCR assay comprised of $2.5 \mu \mathrm{l}$ cDNA, $10 \mu \mathrm{l}$ Primer Design PrecisonPLUS qPCR Master Mix $1 \mu \mathrm{M}$ Forward (5'-ACA GGT ACG TTA ATA GTT AAT AGC GT -3'), $1 \mu \mathrm{M}$ Reverse (5'-ATA TTG CAG CAG TAC GCA CAC A-3') primers and $0.2 \mu \mathrm{M}$ Probe (5'-FAM-ACA CTA GCC ATC CTT ACT GCG CTT CGNFQ-3') targeting the Betacoronavirus E-gene ${ }^{1 .}$ The real-time RT-PCR assay was performed on an Applied Biosystems ABI 7500 Fast Real-time PCR machine (Applied Biosystems, Foster City, CA, USA) with cycling conditions $95^{\circ} \mathrm{C}$ for $2 \mathrm{~min}$, $95^{\circ} \mathrm{C}$ for $5 \mathrm{~s}, 60^{\circ} \mathrm{C}$ for $24 \mathrm{~s}$. SARS-CoV cDNA $(\mathrm{Ct} \sim 30)$ was used as a positive control.

\section{IFITM3 SNP analysis}


292 PCR was performed on genomic DNA extracted from patient's granulocytes (using

293 QIAamp DNA Mini Kit, QIAGEN) to amplify the exon 1 rs12252 region using

294 forward (5'-GGAAACTGTTGAGAAACCGAA-3') and reverse (5'-

295 CATACGCACCTTCACGGAGT-3') primers ${ }^{2}$.

296

297

298

299

300

301

302

303

304

305

306

307

308

309

310

311

312

313

314

315

316

317

318

319

320

321

322

323

324

325

326

327

328

329

330

331

332

333

334

335

336

337

338

339

340

\section{Cytokine analysis}

Patient's plasma was diluted 1:4 before measuring cytokine levels (IL-2, IL-4, IL-6, IL-8, IL-10, IL-12p70, IL-17A， IL-1 $\beta, \quad$ IFN- $\alpha, \quad$ MIP-1 $\alpha, \quad$ MIP-1 $\beta, \quad$ MCP-1, CD178/FasL, granzyme B, RANTES, TNF, IFN- $\gamma$ ) using the Human CBA Kit (BD Biosciences, San Jose, California, USA). For RANTES, sera/plasma was also diluted to 1:50. Healthy donors D6-D10 were of a mean age of 32 (range 22-55 years; $40 \%$ females).

\section{Whole blood staining and flow cytometry}

Fresh whole blood $\left(200 \mu 1\right.$ per stain) was used to measure $\mathrm{CD} 4^{+} \mathrm{CXCR} 5^{+} \mathrm{ICOS}^{+} \mathrm{PD} 1^{+}$ follicular $\mathrm{T}$ cells (Tfh) and $\mathrm{CD} 3^{-} \mathrm{CD} 19^{+} \mathrm{CD} 27^{\mathrm{hi}} \mathrm{CD} 38^{\mathrm{hi}}$ antibody-secreting $\mathrm{B}$ cell (ASC; plasmablast) populations as described ${ }^{3}$ as well as activated HLA$\mathrm{DR}^{+} \mathrm{CD} 38^{+} \mathrm{CD} 8^{+}$and HLA-DR ${ }^{+} \mathrm{CD} 38^{+} \mathrm{CD} 4^{+} \mathrm{T}$ cells, inflammatory $\mathrm{CD} 14^{+} \mathrm{CD} 16^{+}$and conventional CD14+ monocytes, activated HLA-DR ${ }^{+} \mathrm{CD} 3{ }^{-} \mathrm{CD} 56^{+} \mathrm{NK}$ cells, as per the specific antibody panels (Supplementary Table 1; gating strategy is presented in Supplementary Fig.1). After the whole blood was stained for 20 mins at room temperature (RT) in the dark, samples were lysed with BD FACS Lysing solution, washed and fixed with 1\% PFA. Granzymes/perforin staining (patient d20) was performed using the eBioscience Foxp3/Transcription Factor Staining Buffer Set after the lysis step. All the samples were acquired on a LSRII Fortessa (BD). Flow cytometry data were analyzed using FlowJo v10 software. Healthy donors D1-D5 were of a mean age of 35 (range $24-42$ years, $40 \%$ females).

\section{Detection of IgG and IgM antibodies in SARS-CoV-2 -infected vero cells}

Immunofluorescence antibody tests for the detection of IgG and IgM were performed using SARS-CoV-2-infected vero cells that had been washed with PBS and methanol/acetone fixed onto glass slides. Ten $\mu \mathrm{L}$ of a $1 / 20$ dilution of patient plasma in PBS from days 7, 8, 9 and 20 were incubated on separate wells for 30 mins at $37^{\circ} \mathrm{C}$, then washed in PBS and further incubated with $10 \mu \mathrm{L}$ of FITC-conjugated goat anti-human IgG and IgM (Euroimmun, Lübeck, Germany) before viewing on a EUROStar III Plus fluorescent microscope (Euroimmun). Prior to detection of $\operatorname{IgM}$ antibodies, samples were pre-treated with RF-SorboTech (Alere, Rüsselsheim, Germany) to remove IgG antibodies and rheumatoid factors, which may cause falsenegative and false-positive IgM results, respectively.

\section{Reference}

1. Corman, V.M. et al. Euroservaillance 25, doi: 10.2807/1560-

7917.ES.2020.25.3.2000045 (2020).

2. Clemens, E.B. et al. Immunol \& Cell Biol 94, 367-377 (2016).

3. Koutsakos, M. et al. Sci Transl Med 10 (2018).

\section{Data availability}


341 The data that support the findings of this study are available from the corresponding

342 author upon request. Raw FACS data are shown in the manuscript.

343

344

345

346

347

348

349

350

351

352

353

354
Supplementary Table 1. Whole blood immunophenotyping and antibody panels used in our immune assays.

Supplementary Figure 1. Flow cytometry gating strategy for immune cell subsets. Gating panels are shown for (a) $\mathrm{CD} 27^{\text {hi }} \mathrm{CD} 38^{\text {hi }}$ ASCs and activated $\mathrm{ICOS}^{+} \mathrm{PD} 1^{+} \mathrm{Tfh}$ cells; (b) activated $\mathrm{CD} 38^{+} \mathrm{HLA}_{-\mathrm{DR}}{ }^{+} \mathrm{CD} 8^{+}$and $\mathrm{CD} 4^{+} \mathrm{T}$-cells, activated $\mathrm{HLA}_{-\mathrm{DR}}{ }^{+} \mathrm{NK}$ cells and lineage $\mathrm{CD}^{-} 4^{+} \mathrm{CD} 16^{+}$monocytes; and (c) granzymes $(\mathrm{GZM}) \mathrm{A} / \mathrm{B} / \mathrm{K} / \mathrm{M}$ and perforin expression on $\mathrm{CD}^{+} / \mathrm{CD} 4^{+} \mathrm{T}$-cells and activated $\mathrm{CD} 38^{+} \mathrm{HLA}-\mathrm{DR}{ }^{+} \mathrm{CD} 8^{+} / \mathrm{CD} 4^{+}$T-cells. 
a

a
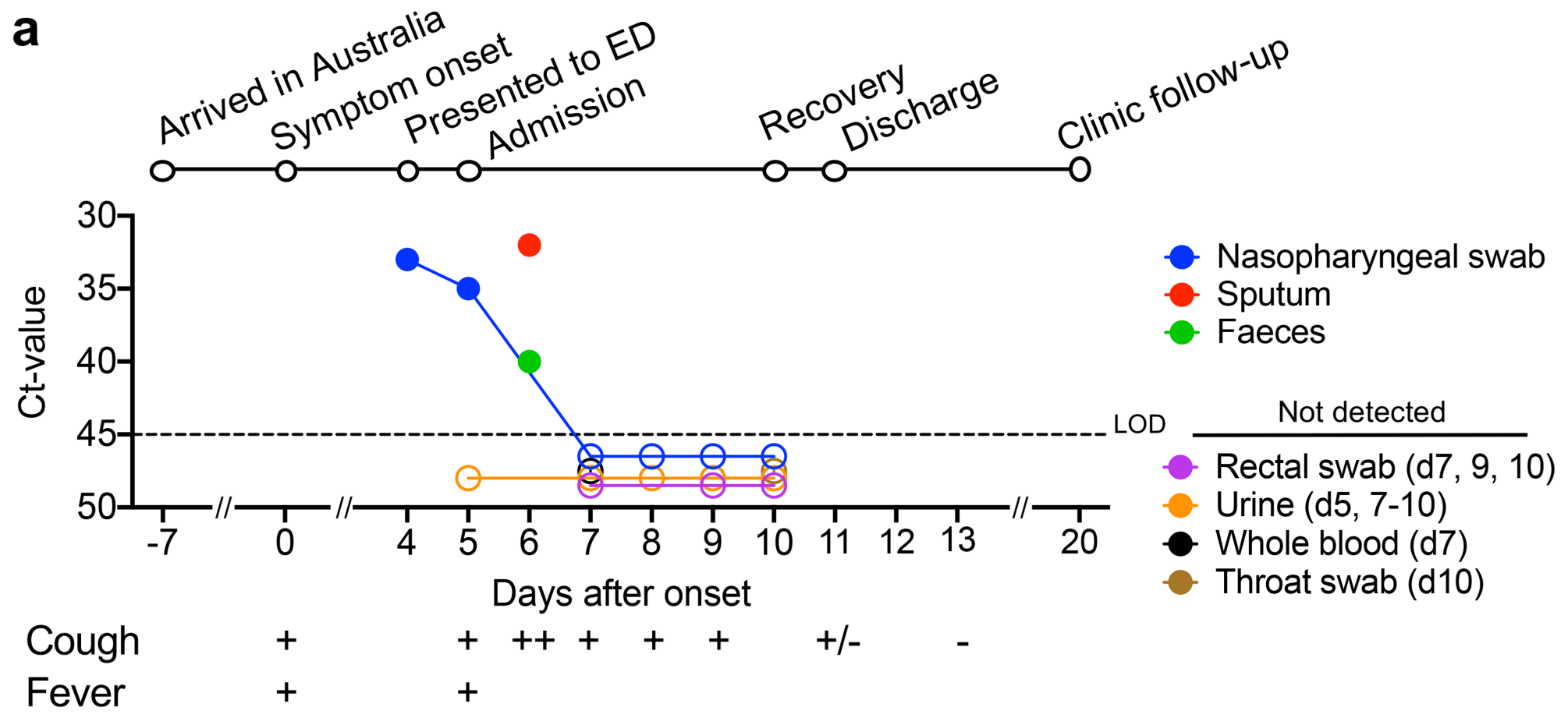

b

Day 5

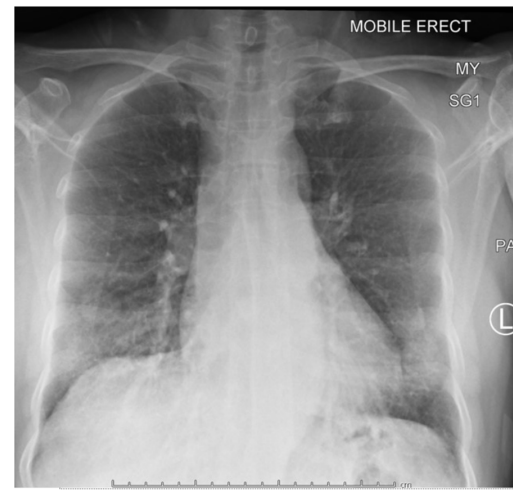

d Neg Patient
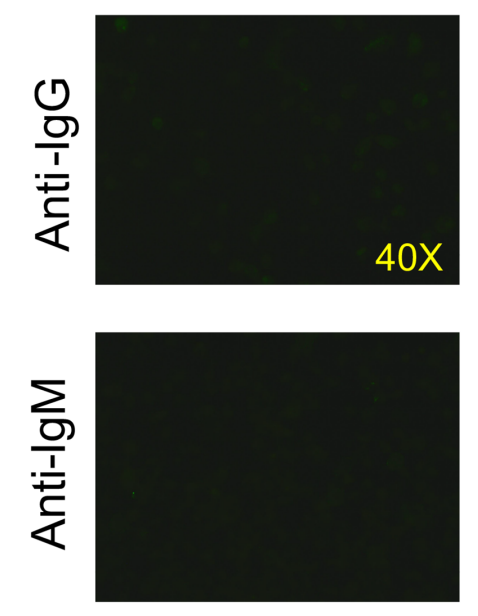

椋
Day 7

Day 8
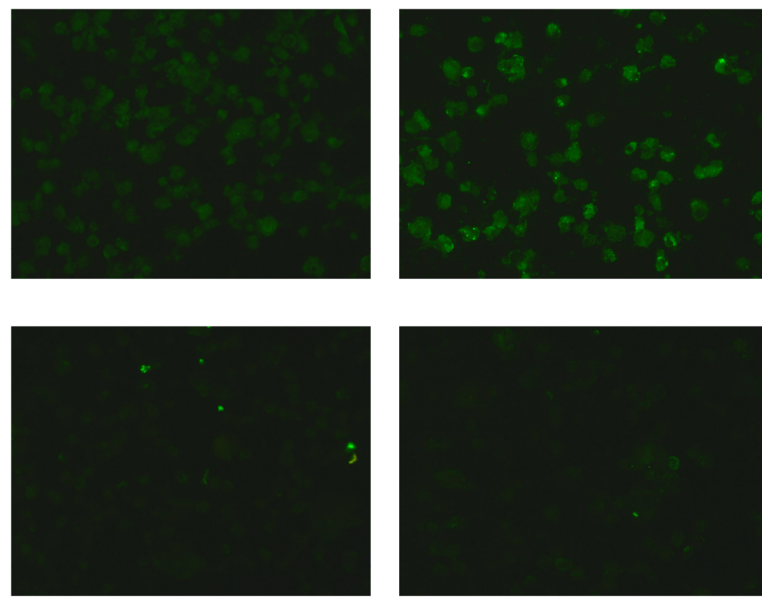

C

COVID-19 patient

\begin{tabular}{|c|c|cccc|}
\hline & Neg & $\mathbf{d} 7$ & $\mathbf{d} 8$ & $\mathbf{d} 9$ & $\mathbf{d} 20$ \\
\hline Anti-lgG & 0 & $1+$ & $2+$ & $3+$ & $3+$ \\
Anti-lgM & 0 & $+/-$ & $+/-$ & $2+$ & $3+$ \\
\hline
\end{tabular}

Day 9

Day 20
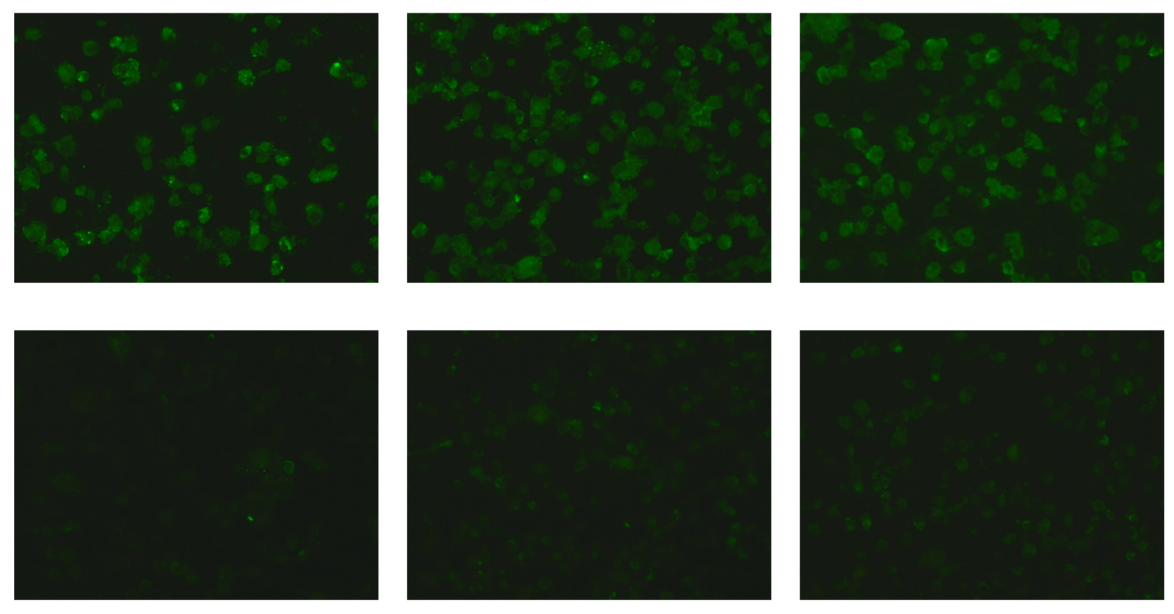

Figure 1. Thevarajan et al 
medRxiv preprint doi: https://doi.org/10.1101/2020.02.20.20025841; this version posted February 23, 2020. The copyright holder for this preprint (which was not certified by peer review) is the author/funder, who has granted medRxiv a license to display the preprint in perpetuity.

It is made available under a CC-BY-NC-ND 4.0 International(10) $\$$ elD-19

a

COVID-19 patient

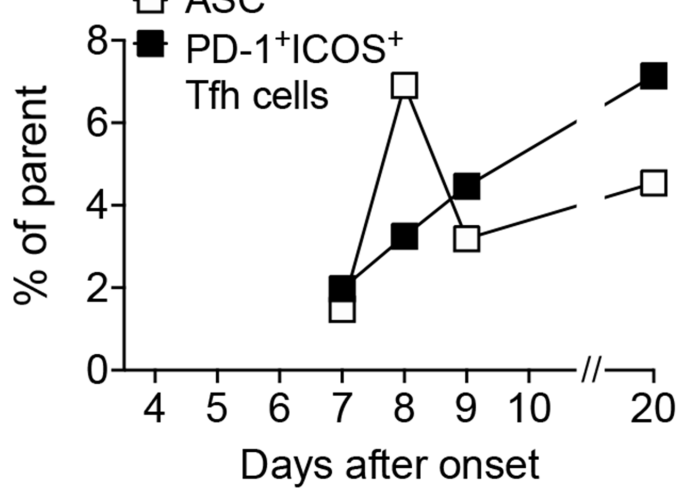

b

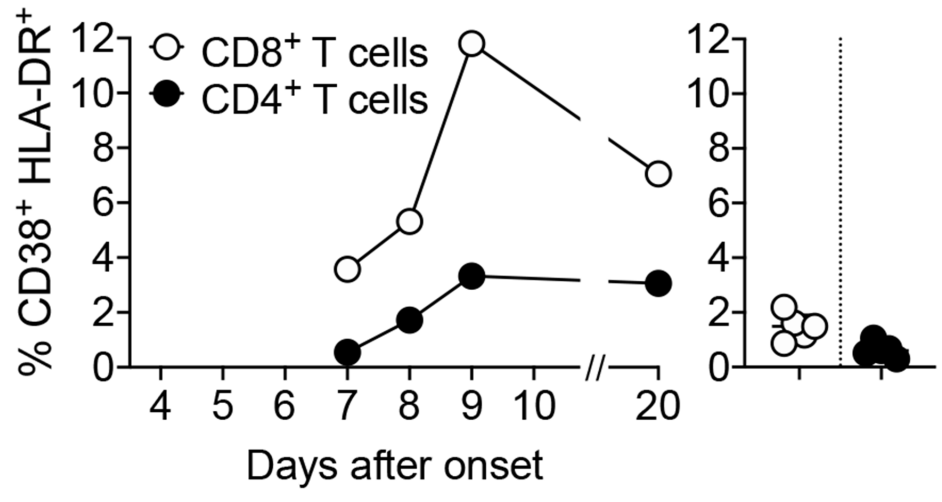

Healthy

d7 $\quad \mathrm{d} 8$

d9

d20 Healthy

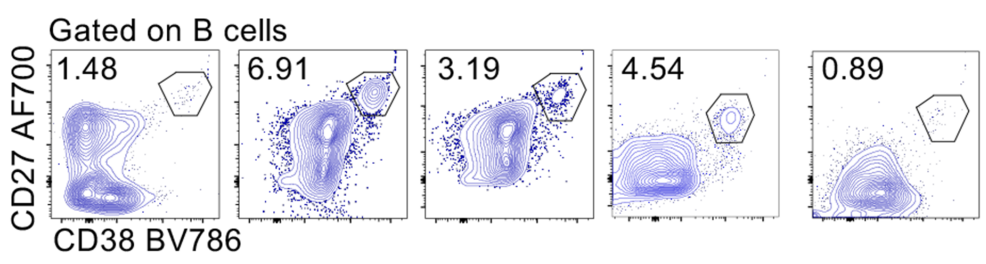

Gated on $\mathrm{CXCR5}^{+} \mathrm{CD} 4{ }^{+} \mathrm{T}$ cells
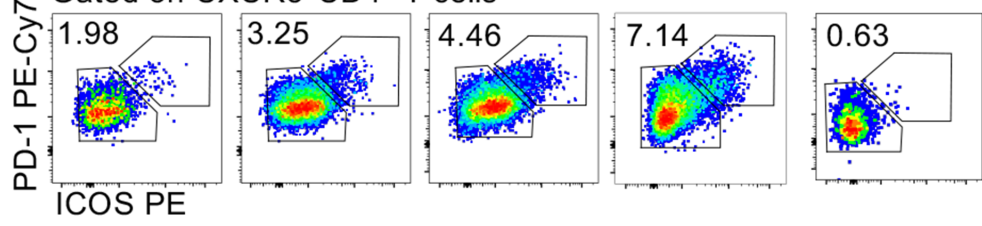

Gated on $\mathrm{CD}^{+} \mathrm{T}$ cells
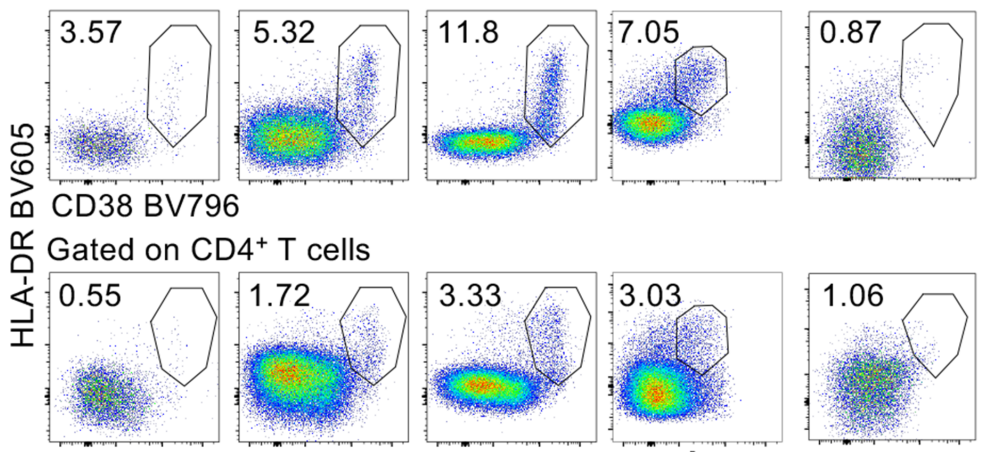

d20 Granzymes/
perforin expression

C
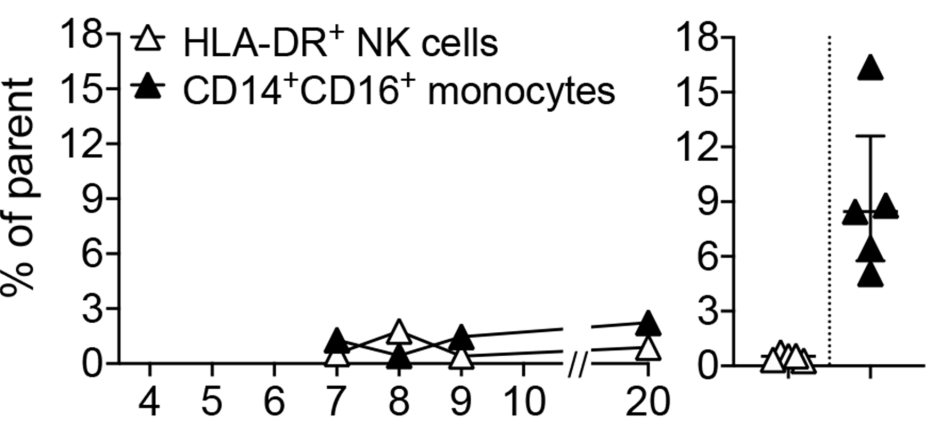

Days after onset

$\mathrm{CD}^{+} \mathrm{T}$ cells vs. $\mathrm{CD}^{2} 8^{+} \mathrm{HLA}-\mathrm{DR}^{+}$
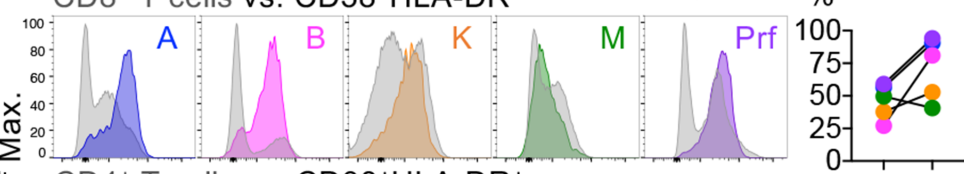

$\mathrm{CD}^{+} \mathrm{T}$ cells vs. $\mathrm{CD} 38^{+} \mathrm{HLA}^{-\mathrm{DR}^{+}}$
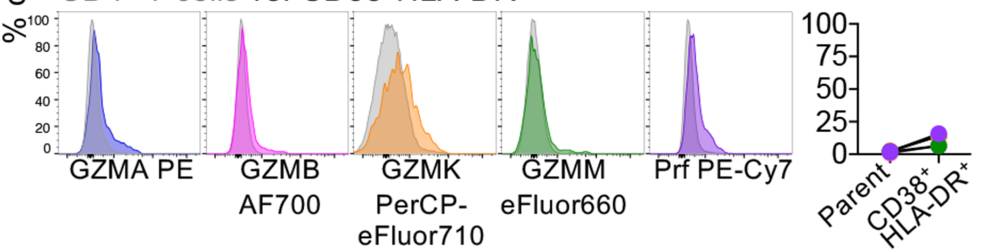

\section{COVID-19}

d7

\& Gated on $\mathrm{CD}^{2} 6^{+} \mathrm{NK}$ cells

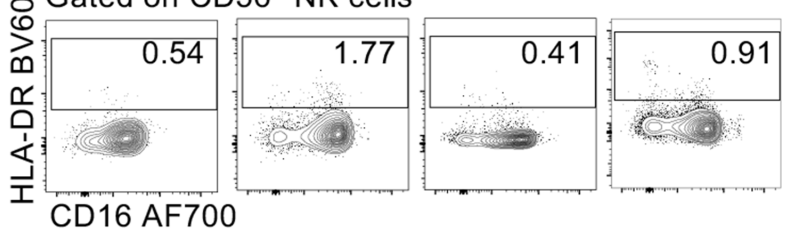

Gated on HLA-DR ${ }^{+}$monocytes

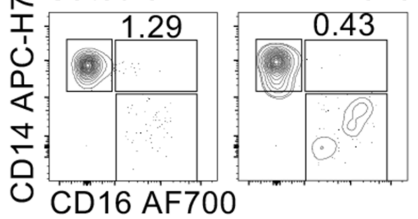

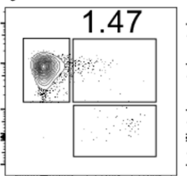
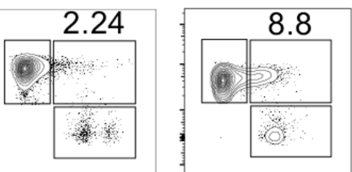

\section{d} 60000
40000
20000 \begin{tabular}{rr}
$\overline{5}$ & 100 \\
\hline $\mathrm{Q}$ & 60 \\
40 \\
20 \\
0
\end{tabular}

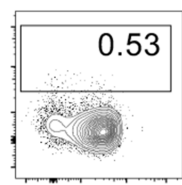

Healthy

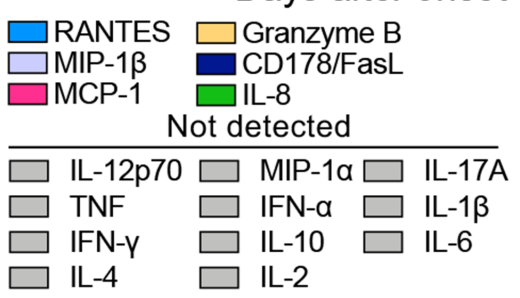

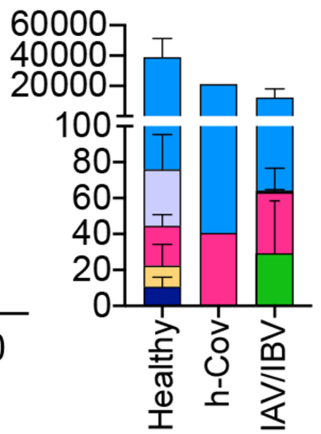

e

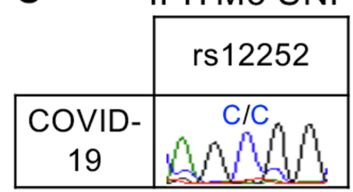

